
\title{
$\begin{array}{ll}\text { Research Square } & \begin{array}{l}\text { Preprints are preliminary reports that have not undergone peer review. } \\ \text { They should not be considered conclusive, used to inform clinical practice, } \\ \text { or referenced by the media as validated information. }\end{array}\end{array}$ \\ Understanding Reasons for Lack of Acceptance in HIV Programs Among Indigenous: a Qualitative Study in Indonesia
}

Elfride Irawati Sianturi ( $\nabla$ ira_sianturi@yahoo.co.id )

Universitas Cenderawasih Fakultas Matematika dan Ilmu Pengetahuan Alam https://orcid.org/0000-00018562-9956

\section{E Latifah}

Muhammadiyah University of Magelang: Universitas Muhammadiyah Magelang

\section{S N Soltief}

Dok II Hospital

\section{R Sihombing}

PKVHI

\section{E S Simaremare}

Universitas Cenderawasih Fakultas Matematika dan IImu Pengetahuan Alam

\section{Effendy}

Gadjah Mada University Faculty of Medicine, Public Health, and Nursing: Universitas Gadjah Mada Fakultas Kedokteran Kesehatan Masyarakat dan Keperawatan

\section{A N Probandari}

Sebelas Maret University Faculty of Medicine: Universitas Sebelas Maret Fakultas Kedokteran

\section{S Suryawati}

Gadjah Mada University Faculty of Medicine Public Health and Nursing: Universitas Gadjah Mada Fakultas Kedokteran Kesehatan Masyarakat dan Keperawatan

\section{K Taxis}

Groningen University Faculty of Mathematics and Natural Sciences: Rijksuniversiteit Groningen Faculty of Science and Engineering

\section{Research}

Keywords: HIV/AIDS, Papuan, Behavior changes, indigenous people, Indonesia

Posted Date: September 14th, 2021

DOI: https://doi.org/10.21203/rs.3.rs-868822/v1

License: (9) (1) This work is licensed under a Creative Commons Attribution 4.0 International License. Read Full License 


\section{Abstract}

Background: Melanesians are Indigenous Papuans that are racially and culturally different from most Indonesians. Poverty and inequalities remain high in this region despite having the highest revenues. Furthermore, Papua has the highest HIV prevalence rate, which is 24 times higher than other regions. Therefore, this study aimed to develop an understanding of the acceptance of HIV programs among Papuans.

Methods: This is a qualitative study carried out using the grounded theory with data collected from 23 Papuans through semi-structured face-to-face interviews. All interviews were conducted in Bahasa Indonesia, audiorecorded, summarized, and transcribed for analysis.

Results: The results showed that to "keep being a good Papuan," emerges from 4 interconnected categories, including 1) Culture and Religion, 2) Dealing with modernisms, 3) Tailoring program and 4) Stigma reduction. As a substantive theory underpinning the experiences of indigenous people with the programs, "Keep being a good Papuan" was a way of overcoming a series of problems and dealing with modernism to eliminating HIV. This is largely focused on the local culture, therefore any adjustment needs to balance keeping their tradition and welcoming modernism.

Conclusions: Therefore, the future of the programs needs to be agreed upon, funded, implemented, measured, and achieved. One of the strategies used to achieve this is by elaborating a supportive culture and communitybased interventions. Further, implementation needs to be prioritized to integrate and improve the quality of the programs due to the needs of the community and the available resources.

\section{Background}

The Asian region is home to over 5 million people living with HIV (PLWH) with 3 quarters of the total number of PLWH residing in China, India, and Indonesia (1). The most recent data showed that more than half a million PLWH live in Indonesia. Irrespective of the fact that Indonesia provides free antiretroviral (ART) drugs, relatively $50 \%$ of PLWH that are aware of their status were not on ART (2). This is followed by an increased number of AIDS-related deaths, which is approximately $68 \%$. According to prior study (3), the level of non-adherence and stigma among PLHW remain high. The complex problem associated with this disease is based on the fact that more than $60 \%$ of PLWH are within the ages of 15 to 24 years old and HIV transmission mode within the 33 provinces varies.

Indonesia consists of relatively 17 thousand islands, and Papua is located in the eastern part. Indigenous Papuans are of Melanesian heritage, a people racially and culturally different from most Indonesians. Conversely, HIV prevalence in this area is approximately 24 times higher than in the other regions. In addition, there is a generalized epidemic with $2.4 \%$ HIV prevalence among the population within the ages of 15 to 24 years old. This tends to be more prevalent and complex in the highlands than Papua's coastal area, which is also the third most heavily affected Indonesian province. With a few exceptions, HIV awareness programs have been promoted to the general population. A prior study stated that unprotected sexual activities and escapades drive the transmission of the HIV virus in Papua among young people compared to other regions (4). 
HIV problems expanded to social-cultural inconsistencies since the patriarchal system is strongly tied to the Papuans daily activities. Furthermore, gender inequalities were highlighted because women are usually at risk. This is even harder for those residing in the highlands because the men have multiple partners. Prior studies stated that Papuans are hesitant to use a condom, and only less than 2 percent of men tend to protect themselves (5).

Decentralization was implemented to improve the performance of health facilities. The government established over 100 primary health centers to test and treat those diagnosed to be HIV positive (6). This helped Papuans receive proper access to healthcare facilities, although distance remains a challenge (7). Besides health care providers, community (8) and faith-organization leaders have been encouraged to running HIV programs among Papuans. It focuses on behavioral change by creating awareness on sexually transmitted diseases and the use of condoms. Furthermore, this study aimed to develop an understanding of the resistance to accept HIV programs by the indigenous people residing in the most eastern part of Indonesia.

\section{Methods}

\section{Research setting}

This study was carried out in Papua, an island that constitutes 2 different countries. First is the land of Papua, which is part of the Republic, followed by New Guinea, an island with a population of 3 million inhabitants contributing 1.51 percent of Indonesia's inhabitants and less than one-fourth in the country. Therefore, population density is extremely low, approximately 8 to 9 persons per square kilometer, however, relatively 40 thousand PLWH inhabit this region. The poor natives residing in the highland areas are isolated compared to tribes in the coastal regions. They are different from the rest of Indonesians, and as the most populated Islamic country worldwide, more than $90 \%$ of Papuans are Christians, especially Catholics, and it affects their daily activities.

\section{Study design}

This is a qualitative research with data collected through semi-structured interviews. Prior study (9) stated that this study was aimed to develop an understanding of the indigenous resistance to accept HIV programs in the most eastern part of Indonesia for the past 15 years. It is also associated with the implementation of activities that trigger the acceptance of this process among Papuans. The study was approved by the Ethics Commission, Faculty of Medicine, Public Health, and Nursing, Universitas Gadjah Mada (number: KE/FK/0507/EC/2018).

\section{Research Team}

The research team had diverse backgrounds, which includes pharmacy, nursing, sociology, and medicine. In addition, 4 of the team members have master's degrees while 5 of them have PhD degrees. The interviewers were all females, consisting of an exception (RS), with the majority extensively experienced in carrying out qualitative interviews. This was performed in Bahasa Indonesia, the national language. All interviews took place in a private location agreed by the participants and interviewers, consisting of experienced pharmacists, nurses, and HIV counsellors. 
A purposive sampling strategy was used to select indigenous people that self-identified themselves either as implementers or recipients of the HIV programs carried out in the past 3 years before the commencement of this study. Meanwhile, it was carried out in Papua and participants were dispersed on the highlands and coastal areas in order to acquire relevant contextual information during the coding and categoric phase. The participants from the highlands were represented by Wamena and Timika, while those from the coastal areas include Merauke, Serui, and Jayapura. This inclusion attempts to prove that people residing in the coastal areas are open to modernism compared to those on the highland. Subsequently, 4 participants from each area, including 2 women and 2 men, were interviewed. To be completely saturated, at least 20 participants need to be included. The assistance of healthcare providers in each location aided the participants to participate in this study. They were also familiar with all interview questions as reported in previous research. Before the interviews were conducted, ethical approval or signed consent was obtained from each participant. All interviews took place in private locations as agreed on by both the participants and interviewers and were audio-recorded. It was conducted in Indonesian, which is the national language. The participant's information was kept confidential to avoid any issues in the future.

\section{Data Collection}

Data was collected through face-to-face in-depth interviews between July and September 2018. The participants were asked to describe their experience in accordance with the increase in HIV cases in their area, as shown in Appendix 1. The interviewers also took field notes during the analysis process to add ideas. This includes important information such as the interview setting and the participant's reaction while explaining certain questions (10). All audio recordings were transcribed verbatim, and the process was double-checked. The participants were unwilling to read the transcripts, besides each was given a unique identifier composed of gender, age, and region. The interview was stopped, immediately the participants were saturated. Theoretical saturation was achieved with 23 interviews since there were no more differences between the experienced participants that ran the program and the recipients (10). There was no repetition, and the consolidated criteria for reporting qualitative research interviews (COREQ) guided this study.

\section{Data Analysis}

Data were analyzed using the Atlas Ti Version 8.4 software with transcripts coded by 2 analysts adopting a similar approach as reported in a previous study (11). All transcripts were read and re-read to develop an initial framework which was refined during coding. Based on Strauss and Corbin's theory, specific categories were developed and collectively identified emerging themes (12). Discussions between the 2 analysts resolved disagreements in the analysis. The themes were finally mapped with an existing larger framework on behavioral change (13). Memos were used to note important information during the interview, and they helped to build the codes and categories that emerged from the data.

\section{Trustworthiness \& Rigor}

The participants were interviewed based on 3 experienced qualitative studies taking into consideration trustworthiness and rigor. The results demonstrated accuracy, relevance, flexibility, and neutrality based on the 
transcription, re-read, memoing, and saturation (14). One interviewer and a team member checked the accuracy of the interpretation.

\section{Results}

This study involved 23 participants, comprising 11 women and 12 men [Table 1]. Meanwhile, their mean age was 52 years, and none of the eligible persons refused to participate when they were contacted. Additional participants' characteristics are shown in Table 1. This study identified the core of the category "keep being a good Papuan" which depicts the indigenes' perception of the program in the past 15 years and the way it needs to be run in order to be highly accepted among the community despite the existing skepticism. The composition between implementers and recipients is shown in Table 2.

Table 1

Characteristics of Participants $(n=23)$

\begin{tabular}{|c|c|c|c|c|c|c|}
\hline \multirow{2}{*}{\multicolumn{2}{|c|}{ Participants $(n=23)$}} & \multicolumn{2}{|l|}{ Highland } & \multicolumn{3}{|l|}{ Coastal } \\
\hline & & Wamena & Timika & Merauke & Serui & Jayapura \\
\hline \multicolumn{7}{|c|}{ Mean age 52 (range: $45-68$ years) } \\
\hline \multirow[t]{2}{*}{ Gender } & Male $52 \%(n=12)$ & 2 & 3 & 2 & 2 & 3 \\
\hline & Female $48 \%(n=11)$ & 2 & 2 & 2 & 2 & 3 \\
\hline \multirow[t]{2}{*}{ Working status } & Pension 40\% (n = 9) & 1 & 2 & 2 & 3 & 1 \\
\hline & Actively working $60 \%(n=14)$ & 3 & 3 & 2 & 1 & 5 \\
\hline
\end{tabular}


Table 2

The composition between implementers and recipients among participants

\begin{tabular}{|c|c|c|c|c|c|}
\hline Coding Name (Pseudonym) & Age & Sex & Location & Status & Profession \\
\hline $\mathrm{F} 1$ & 52 & Female & Wamena & Recipient & Housewife \\
\hline $\mathrm{F} 2$ & 50 & Female & Wamena & Recipient & Teacher \\
\hline F3 & 54 & Female & Timika & Recipient & Priest \\
\hline $\mathrm{F} 4$ & 53 & Female & Timika & Implementer & Retired \\
\hline F5 & 52 & Female & Merauke & Implementer & Retired \\
\hline F6 & 52 & Female & Merauke & Recipient & Nurse \\
\hline F7 & 49 & Female & Serui & Recipient & Priest \\
\hline F8 & 45 & Female & Serui & Implementer & Housewife \\
\hline F9 & 45 & Female & Jayapura & Recipient & Politician \\
\hline F10 & 48 & Female & Jayapura & Recipient & Lawyer \\
\hline F11 & 50 & Female & Jayapura & Implementer & Nurses \\
\hline M1 & 52 & Male & Wamena & Implementer & Retired \\
\hline M2 & 56 & Male & Wamena & Implementer & Retired \\
\hline M3 & 50 & Male & Timika & Implementer & Priest \\
\hline M4 & 69 & Male & Timika & Implementer & Retired \\
\hline M5 & 50 & Male & Timika & Recipient & Employee \\
\hline M6 & 55 & Male & Merauke & Implementer & Retired \\
\hline M7 & 45 & Male & Merauke & Implementer & Politician- Retired \\
\hline M8 & 45 & Male & Serui & Recipient & Priest \\
\hline M9 & 48 & Male & Serui & Implementer & Government employee \\
\hline M10 & 50 & Male & Jayapura & Implementer & Government employee \\
\hline M11 & 67 & Male & Jayapura & Recipient & Retired \\
\hline M12 & 55 & Male & Jayapura & Recipient & Retired \\
\hline
\end{tabular}


Table 3

Linkage between one category and another in the paradigm scheme through examples of quotes.

\begin{tabular}{|lll|}
\hline $\begin{array}{l}\text { Themes being } \\
\text { a good } \\
\text { Papuan }\end{array}$ & $\begin{array}{l}\text { Categories } \\
\text { culture- } \\
\text { religion }\end{array}$ & $\begin{array}{l}\text { Quotes a member, I do not have the heart to reject people because they were } \\
\text { wrong in the past. Our religion teaches us to spread love to others. } \\
\text { From my experience, they invited me to capital city for that program. It was } \\
\text { just one day. What do you expect from a day training? HIV is complicated. }\end{array}$ \\
& $\begin{array}{l}\text { dealing with } \\
\text { modernisms }\end{array}$ & $\begin{array}{l}\text { We need to rent boat if you are going to that island. At least we need a } \\
\text { couple hours to reach that place. }\end{array}$ \\
& $\begin{array}{l}\text { tailoring } \\
\text { program }\end{array}$ & $\begin{array}{l}\text { Every year, we have a budget to allocate in specific urgency such as health } \\
\text { issue and we invited scholars to do research. }\end{array}$ \\
& $\begin{array}{l}\text { stigma } \\
\text { reduction }\end{array}$ & $\begin{array}{l}\text { Of course, I heard community abandoned PLHW in one house, nobody fed } \\
\text { them. Then we knew they dead. }\end{array}$ \\
\hline
\end{tabular}

In Table 3, it was discovered that "keep being a good Papuan" emerges from 4 interconnected categories, including 1) Culture and Religion, 2) Dealing with modernisms, 3) Tailoring program and 4) Stigma reduction. As a substantive theory underpinning the experiences of indigenous people with the programs, "Keep being a good Papuan" was a way of overcoming a series of problems and dealing with modernism to eliminating HIV. This is largely focused on the local culture, therefore any adjustment needs to balance keeping their tradition and welcoming modernism.

\section{Culture and Religion Concepts}

Challenges in dealing with modernism and keeping traditional values have never really been counted for by Papuans. Occasionally, people deviate from tradition and religion. Since the early days, the concept of Christianity and local values have had a significant effect on the Papuans' lives. They felt that they need to help PLHW overcome their burden, and these tend to vary.

"We have the ability to cheer, support, and give assurance to HIV patients. As a mother, we treat our children similarly, and there is a need to support them no matter their personality. It is believed that the participation of women aids in tackling this problem immediately. These victims are embraced based on experiences" [Female, 46, Coastal]

Regarding lack of trust in the available HIV medication, Papuans encourage PLHW to adhere to their medication because they believe that it attracts God's forgiveness.

"We believe in the existence of God, and societal norms help us to bound in many ways. There is a need to trust that existing medication needs to be accepted as a form of hope." [Male, 61, Highland]

The Papuans found it difficult to believe that the term ART is merely suppresses rather than kills the virus.

Based on its uncertainties, they accepted that living with HIV is a miracle. To make this program accepted in the community, there need to be testimonies on their survival. 
"In early days, these activities were routinely run in the community. Besides creating awareness, the campaigns motivated the community to have more contact with adherent patients. They are encouraged not to be scared of the virus..." [Male, 68, Coastal]

The participants agreed that deterrent effects need to be excluded from the HIV programs. Meanwhile, the happenings in the early days traumatized both the PLHW and the community. A woman revealed that the way PLHW were treated in the past did not reflect their values. It was further emphasized that HIV is still a burden, although the reaction of the community towards victims is much better.

"It seems just like yesterday when nothing was done except take for granted the fact that someone was HIVpositive. They believed being infected meant immoral acts and disrupted their values. However, they do not have the right to punish anyone. Although, it is difficult to forget." [Female, 54, Highland]

This disease triggered several issues, including gender inequality. The patriarch system is dominant among the Papuans; however, it is perceived as a 2-edged sword by the women because it protects them from harassment and, at the side, time blames them for being the source of transmission.

"Our values teach them to respect women, which is evident especially in Serui [name of a district] because it is believed that women give birth to the younger generations. It is also believed that their descendants are bound to be unhealthy, supposing their women are HIV-positive" [Female, 47, Coastal]

"The communities are usually hesitant to mention HIV rather, they refer to it as women's disease. They feel embarrassed, and it serves as a reminder that they are the source of the virus. This is really degrading for the women. "[Female, 47, Coastal]

The men accept all forms of gender equality because they believe inequalities tend to affect their daughters.

"To be honest, parents are bound not to allow their daughters to get married to infected males. They prefer to kick against the marriage rather than allow their daughters to suffer. "[Male, 60, Highland]

Dealing with modernisms

In this era, participants agreed that traditions need to be integrated with modernism. Furthermore, some adjustments have to be made. Papuans also discovered that internet use is advantageous in terms of connecting with people all over the world. Irrespective of this fact, Papuans prefer face-to-face meetings when creating awareness about HIV. The information that HIV is transmitted by sexual intercourse is a taboo.

"As a leader in this community, it has been communicated that HIV is a problem. The leader further stated that they intend to ensure that this information reaches members residing in remote areas. They are isolated from the urban regions, and they also deserve to be informed about the seriousness of this disease and the need for it to be tackled in their communities. However, information regarding the spread of this virus is effectively conveyed face-to-face. "[Male, 45, Coastal]

A woman stated that the relevance of getting children in the highlands informed. 
"It is an undeniable fact that the government promotes HIV prevention through the media, especially radio and community health center programs. However, only a few people listen to the radio. It was also discovered that community health centers combined HIV programs with integrated services post. Therefore, they are mainly concerned about children and female" [Female, 45, Highland]

In the early days, Papuans hardly accepted used condoms which are perceived as a preventive measure however women discovered that the modern lifestyle causes young people to have early sexual debut. Regarding the evidence that condom use is an effective preventive measure, women had no option but to accept it with a heavy heart.

"Of course, as parents, it is difficult to accept that young people engage in early sexual debut. This is an undeniable condition therefore condom is needed to prevent the transmission of the virus. Don't you think as parents it is easier to inform the children about the use of use? Of course not... "[Female, 52, Coastal]

Men were equivocal to this alternative because it is bound to cause problems with their partners.

"I think a condom is useful although it also gives hard tensions to their partners. This indirectly implies the promotion of extramarital sex. "[Male, 68, Coastal]

Tailoring program

Participants reported that adequate efforts are needed to curb the spread of HIV in Papua. They believe that working together with stakeholders tends to be useful. Some sectors such as education, health, women empowerment, and child protection need to be integrated into these programs. It was also revealed that no one size fits all, and to increase acceptance among tribes, they need to be aware that some programs are more effective.

"We collaborated with scholars and all parties brings about Merauke, a successful means of curbing HIV reduction. Hospitals and NGOs are encouraged to carry out studies on reproduction as well as HIV. It was discovered that tribal and religious leaders were in full support of the program. They claimed to be the only district in Papua that successfully curbed the spread of this virus "[Female, 46, Coastal]

Even though the government is the leader of these programs, the participants revealed that they failed to recruit the appropriate personnel. The grand design of the HIV program was missed from the government's views.

"Government needs to employ competent people in this field. They have to be from the local government, educational, and health departments as well as be able to work together. They need to map the needs of each area and collaborate with local or international organizations in terms of adjusting to their requirements. Presently, all stakeholders tend to engage in similar programs, and this tends to overlap. "[Male, 62, Highland]

Collaboration between faith organizations and customary institutions is necessary and needs to be continued. Working with them makes the acceptance of these programs easier. Besides, deterrent effects are reduced, and Papuans tend to listen to these organizations. The participants agreed that Papuans respect their faith and tribe leaders. 
"Our experiences working with churches showed that many young people from remote and urban areas were enthusiastic about attending the programs. They need to invite them to participate in these initiatives actively, it is believed that they are able to find a way to curb the spread of HIV and the community needs to accept PLHW as part of the" [Male, 50, Coastal]

A woman reported that the government underestimated their initiative to be part of these programs. Based on the government's perspective, Papuans seem to be users rather than implementers.

"... They do not know the reason the government invited them to attend the training however, after they returned to the community, there was no avenue for them to be part of the programs. They were trained to be users, not implementers" [Female, 47, Coastal]

Stigma reduction

Papuans concluded that some programs failed after HIV prevalence increased over time and the stigma was normalized among PLHW. The participants were concerned with the fact that activities initiated to reduce stigma were not yet included in the programs. Meanwhile, men and women had different opinions regarding its performance in the community. One of the men stated that stigma reduction is carried out physically.

"Shelters were built for them to meet people with similar condition and in order not to feel excluded." [Male, 68, Coastal]

Conversely, women encourage the support of family members. They help them to visit health facilities and remind PLHW to be faithful. Moreover, women understand the fact that disclosure status is unnecessary because they know it has a greater impact on the family.

"There is a need to look after the family because it is believed that members are willing to help, although sometimes this is impossible because they feel excluded by the community. It is understandable when parents hide their children's status as long as they are able to help them. This need not be neglected, and their decisions need to be respected "[Female, 52, Highland]

\section{Discussion}

This research revealed the reasons for indigenous resistance and the engagement in sexual acts in Papua, an area with the highest HIV prevalence in Indonesia. It was discovered that "keep being a good Papuan" is the core of categories in which culture-religion deals with modernisms, tailoring programs, and the impact of stigma reduction on the acceptance of HIV initiatives among Papuans.

Similar to a preliminary study, which stated that issues on health-related policy are complex and interrelated with individual, social, contextual, and environmental factors (15). Recently, varied interventions and stakeholders were invited to execute these programs to encourage acceptance among the Papuans (16); however, misconceptions remain common. The community hardly believes that ART serves as HIV drug because they know that it is used to suppress the virus and not kill (17). Papuans discovered that there is no additional information about these drugs to convince them that HIV is a manageable disease. The health care providers in this area conveyed the lack of knowledge and misperception of ART because they also had similar 
perceptions (11). This leads to skepticism that there is no hope after being diagnosed with HIV, thereby making the situation crucial with the need for immediate rectification.

Similarly, indigenous Papuans, strongly tied to their culture and religion, discovered that they need an exclusive approach (9), (18), (19) to create awareness on HIV programs, including its prevention. Since it is dominantly transmitted by unprotected sexual intercourse and topics on sex are not discussed among Papuans because they are regarded as a taboo (21). Contrary with prior study, they preferred to use face-to-face meetings compared to the use of mass media or internet platforms (22). Even though cultural interventions tend to vary (23) and are complex (24), they easily trigger the indigenes to accept the programs.

On the contrary, women prefer the use of condoms as a preventive measure rather than men (25). As is the case globally, gender inequalities remain common (26). Women discovered that masculinity is equated with dominance, and femininity is typified by subordination to accommodate men with conservative backgrounds. Furthermore, it is impossible for women to erode patriarchy from their daily activities completely. This is because they are unable to refuse their partners' sex. In fact, women discovered that they had HIV and vulnerable to contracting the infection from their partners (27). Therefore, they must participate in these programs (28).

Similar to the indigenous people, Papuans discovered that transformation from traditional to modernism is complicated (19). They stated that modernism brought about certain severe social problems, including poor infrastructure, lack of sufficient health facilities, and the prevalence of HIV. The indigenes are faced with severe problems such as stigma because, physically, they have a different skin color from the rest of Indonesians (29). This is perceived as a double stigma when it one is HIV-positive (30). More options in order to curb this issue have been offered, such as shelter and encouraging family members to help and support PLHW. Nonetheless, the fact that it is useful to collaborate with tribal communities (31) and faith-based organizations (32) increase the number of Papuans willing to participate in these programs. It is better to discuss issues on HIV and ways to deal with the stigma by avoiding its deterrent use during the programs.

This study highlighted many misconceptions the Papuans had about HIV. However, assuming these are tolerated continually, then the community is forced to accept those living with HIV, thereby reducing the stigma. The redefinition of ART as HIV drugs needs to be prioritized, and it changes the fact that it is a chronic disease such as heart failure, epilepsy, and diabetes. Improving the knowledge of HIV transmission and making more contact with PLHW helps the community's perspective (33). Furthermore, the programs need to be measurable (34), and cultural-customs including the readiness to change the community (35) while running these programs, need to be considered. This causes Papuans to be actively engaged.

The strength of this study lies in the inclusion of actively involved women and men. The diversity of people that live in both rural and urban areas enriched the results. Despite the strengths, this study had limitations. It is difficult to generalize the results to other Indonesian areas. Most participants were educated, and the results tend to be different with regard to uneducated people. It is necessary to conduct these programs to continue reducing stigma. Regarding these problems, some issues have to be rectified immediately, and the program has to be based on the needs of the region.

\section{Conclusions}


Therefore, the future of the programs needs to be agreed upon, funded, implemented, measured, and achieved. One of the strategies used to achieve this is by elaborating a supportive culture and community-based interventions. Further, implementation needs to be prioritized to integrate and improve the quality of the programs due to the needs of the community and the available resources.

\section{Abbreviations}

PLWH: people living with HIV

ART: antiretroviral

COREQ: the consolidated criteria for reporting qualitative research interviews

\section{Declarations}

\section{Acknowledgements}

The authors would like to express their gratitude to Papuans who participated in this study

\section{Authors' contributions}

Conceived and designed the study: EIS, KT, SNS, and RBS. Analyzed the data: EIS, KT, EL, AP, CE, RBS, SNS, and ES. Wrote the paper: EIS, KT, EL, CE and AP. All authors read and approved the final manuscript.

\section{Funding}

These authors have no support or funding to report

\section{Data sharing statement}

The data would not be shared outside of participating research institutions. Any queries on how to access the data set should be to the corresponding author or: ira_sianturi@yahoo.co.id

\section{Ethical Approval}

The study was approved by the Ethics Commission, Faculty of Medicine, Public Health, and Nursing, Universitas Gadjah Mada [number: KE/FK/0507/EC/2018].

\section{Participant consent}

All participants, men and women, gave written informed consent.

\section{Consent for publication}

N/A

\section{Competing interests}


The authors have indicated that they have no competing interests

\section{References}

1. UNAIDS. Country factsheets MOROCCO | 2018 HIV and AIDS Estimates Adults and children living with Country factsheets TANZANIA | 2018 HIV testing and treatment cascade People living with HIV Coverage of adults and children. Unaids [Internet]. 2018;1-6. Available from: https://aidsinfo.unaids.org/\%OD

2. UNAIDS. Global report: UNAIDS report on the global AIDS epidemic 2010. 2010.

3. Sianturi El, Perwitasari DA, Islam A, Taxis K. The association between ethnicity , stigma, beliefs about medicines and adherence in people living with HIV in a rural area in Indonesia. BMC Public Health. 2019;18.

4. Irmanigrum Y, Priyono JB, Syahboedin I, Siahaan T, Ruslam P, Sutrisna A. Risk Behavior and HIV Prevalence in Tanah Papua 2006. 2006;113. Available from: https://www.aidsdatahub.org/risk-behavior-and-hivprevalence-in-tanah-papua-2006-results-of-the-ibbs-2006-in-tanah-papua-statistics-indonesia-and-ministryof-health-indonesia-2006

5. Diarsvitri W, Utomo ID, Neeman T, Oktavian A. Beyond sexual desire and curiosity: Sexuality among senior high school students in Papua and West Papua provinces (Indonesia) and implications for HIV prevention. Cult Heal Sex. 2011;13(9):1047-60.

6. Indonesia National AIDS Commission Indonesia, Indonesian National AIDS Commission. Global AIDS Response Progress Reporting Indonesia Country Progress Report 2014. 2014;1:35-110. Available from: http://www.unaids.org/sites/default/files/country/documents/IDN_narrative_report_2014.pdf

7. Heywood P, Choi Y. Health system performance at the district level in Indonesia after decentralization. BMC Int Health Hum Rights. 2010;10(1):1-12.

8. Munro J. Engaging Indigenous Leaders in Tanah Papua 's HIV Responses. 2015;1-2.

9. Corbin J, Strauss A. Basics of Qualitative Research Techniques and Procedures for Developing Grounded Theory FOURTH EDITION [Internet]. 2015. Available from: SAGE

10. Sutton J, Austin Z. Qualitative Research: Data Collection, Analysis, and Management. JCHP. 2015;68(3):226-31.

11. Sianturi E., Latifah E, Probandari A, Effendy C, Taxis K. The daily struggle to take antiretrovirals: a qualitative study in Papuans living with HIV and their healthcare providers. BMJ Open. 2020;10(9).

12. Heath H, Cowley S. Developing a grounded theory approach: A comparison of Glaser and Strauss. Int J Nurs Stud. 2004;41(2):141-50.

13. Kaufman MR, Cornish F, Zimmerman RS, Johnson BT. Health behavior change models for HIV prevention and AIDS care: Practical recommendations for a multi-level approach. J Acquir Immune Defic Syndr. 2014;66(SUPPL.3):250-8.

14. Krefting L. Rigor in Qualitative Research: The Assessment of Trustworthiness. Am J Occup Ther. 1991;45(3):214-22.

15. McCree DH, Beer L, Prather C, Gant Z, Harris N, Sutton M, et al. An approach to achieving the health equity goals of the national HIV/AIDS strategy for the united states among racial/ethnic minority communities. Public Health Rep. 2016;131(4):526-30. 
16. Hermanus A, Zeth M, Asdie AH, Mukti AG, Mansoden J. Perilaku dan Resiko Penyakit HIV-AIDS di Masyarakat Papua Studi Pengenbangan Model Lokal Kebijakan HIV-AIDS. Manaj Pelayanan Kesehat. 2010;13(04):206-19.

17. Weiss JJ, Konstantinidis I, Boueilh A, Fierer DS, Gardenier D, Barber MG, et al. Illness perceptions, medication beliefs, and adherence to Antiretrovirals and Medications for Comorbidities in Adults With HIV infection and hypertension or chronic kidney disease. J Acquir Immune Defic Syndr. 2016;73(4):403-10.

18. Safren SA, Wingood G, Altice FL. Strategies for primary HIV prevention that target behavioral change. Clin Infect Dis. 2007;45(SUPPL. 4).

19. Persoon G, Eindhoven M, Modina RB, Aquino DM. Indigenous Peoples in Southeast Asia. 2007.

20. Ananta A, Utami DRWW, Handayani NB. Statistics on Ethnic Diversity in the Land of Papua, Indonesia. Asia Pacific Policy Stud. 2016;3(3):458-74.

21. Mullens AB, Kelly J, Debattista J, Phillips TM, Gu Z, Siggins F. Exploring HIV risks, testing and prevention among sub-Saharan African community members in Australia. Int J Equity Health. 2018;17(1):1-12.

22. Hottes TS, Farrell J, Bondyra M, Haag D, Shoveller J, Gilbert M. Internet-based HIV and sexually transmitted infection testing in British Columbia, Canada: Opinions and expectations of prospective clients. J Med Internet Res. 2012;14(2):238-48.

23. Rowan M, Poole N, Shea B, Gone JP, Mykota D, Farag M, et al. Cultural interventions to treat addictions in indigenous populations: Findings from a scoping study. Subst Abus Treat Prev Policy. 2014;9(1).

24. Cornish F, Priego-Hernandez J, Campbell C, Mburu G, McLean S. The impact of Community Mobilisation on HIV Prevention in Middle and Low Income Countries: A Systematic Review and Critique. AIDS Behav. 2014;18(11):2110-34.

25. Jimenez MM, Andrade FCD, Raffaelli M, Iwelunmor J. Heterosexual transmission of HIV in the Dominican Republic: Gendered indicators are associated with disparities in condom use Health behavior, health promotion and society. BMC Public Health [Internet]. 2015;15(1):1-10. Available from: http://dx.doi.org/10.1186/s12889-015-2432-8

26. Negin J, Aspin C, Gadsden T, Reading C. HIV Among Indigenous peoples: A Review of the Literature on HIVRelated Behaviour Since the Beginning of the Epidemic. AIDS Behav [Internet]. 2015;19(9):1720-34. Available from: http://dx.doi.org/10.1007/s10461-015-1023-0

27. Anderson ES, Wagstaff DA, Heckman TG, Winett RA, Roffman RA, Solomon LJ, et al. Informationmotivation-behavioral skills (IMB) model: Testing direct and mediated treatment effects on condom use among women in low-income housing. Ann Behav Med. 2006;31(1):70-9.

28. Gianella S, Tsibris A, Barr L, Godfrey C. Barriers to a cure for HIV in women. J Int AIDS Soc. 2016;19(1):110.

29. Sari EN, Samsuri S. Etnosentrisme dan Sikap Intoleran Pendatang Terhadap Orang Papua. J Antropol IsuIsu Sos Budaya. 2020;22(1):142.

30. Saewyc E, Clark T, Barney L, Brunanski D, Homma Y. Enacted Stigma and HIV Risk Behaviours among Sexual Minority Indigenous Youth in Canada, New Zealand, and the United States. Pimatisiwin [Internet]. 2014;11(3):411-20. Available from:

http://www.ncbi.nlm.nih.gov/pubmed/26793243\%0Ahttp://www.pubmedcentral.nih.gov/articlerender.fcgi? artid=PMC4716820

Page $14 / 15$ 
31. Vlassoff C, Weiss MG, Rao S, Ali F, Prentice T. HIV-related stigma in rural and tribal communities of Maharashtra, India. J Heal Popul Nutr. 2012;30(4):394-403.

32. Kulkarni S, Hoffman S, Gadisa T, Melaku Z, Fantehun M, Yigzaw M, et al. Identifying Perceived Barriers along the HIV Care Continuum: Findings from Providers, Peer Educators, and Observations of ProviderPatient Interactions in Ethiopia. J Int Assoc Provid AIDS Care. 2016;15(4):291-300.

33. Gronholm PC, Henderson C, Deb T, Thornicroft G. Interventions to reduce discrimination and stigma: the state of the art. Soc Psychiatry Psychiatr Epidemiol. 2017;52(3):249-58.

34. Lawrence TJ, James RD. Good health and wellness: Measuring impact through an indigenous lens. Prev Chronic Dis. 2019;16(8):1-5.

35. Abara W, Coleman JD, Fairchild A, Gaddist B, White J. A Faith-Based Community Partnership to Address HIV/AIDS in the Southern United States: Implementation, Challenges, and Lessons Learned. J Relig Health. 2013;54(1):122-33.

\section{Supplementary Files}

This is a list of supplementary files associated with this preprint. Click to download.

- ListInterviewGuide.docx 